\title{
The Association Between Social Support and Impaired Fasting Glucose and Type 2 Diabetes
}

\author{
Yun-Jung Kang ${ }^{1, \dagger}$ and Sang-Nam Park ${ }^{2}$ \\ ${ }^{I}$ Department of Clinical Laboratory Science, Kyungwoon University, Gumi 39160, Korea \\ ${ }^{2}$ Department of Clinical Laboratory Science, Kyungdong University, Wonju 26495, Korea
}

\begin{abstract}
The purpose of this study was to examine the effect of social support on type 2 diabetes by classifying it into diabetes and impaired fasting blood sugar, a pre-diabetic state. Subjects of this study were 22,846 adults aged 30 years or above who agreed and registered to participate in the "Korean Health Examine Cohort (KOEX)" study that simultaneously collects questionnaires and biological samples at 8 university hospitals around the nation. Normal fasting blood sugar was defined as below $100 \mathrm{mg} / \mathrm{dL}$, and impaired fasting blood sugar was defined as 100 125 mg/dL. Diagnosis of diabetes was defined as fasting blood sugar of $126 \mathrm{mg} / \mathrm{dL}$ or above, diagnosis by a doctor, or medication of insulin or oral hypoglycemic agent. Social support groups were divided into 4 groups, and Group 1 (G1) had high positive support and low negative support. This is the reference group with the highest social support. During multivariate analysis, female group (G3) that had high positive support and high negative support showed prevalence of impaired fasting blood sugar 1.19 times higher $(95 \% \mathrm{CI}=1.02 \sim 1.41)$ than $\mathrm{G} 1$. As this study confirmed that social support increases fasting blood sugar of women after correction for socioeconomic status, health behavior, and biological and medical variables, it implies the importance of social relations such as social support in addition to management of personal risk factors for prevention of type 2 diabetes.
\end{abstract}

Key Words: Social support, Type 2 diabetes, Prediabetes, Fasting glucose

\section{INTRODUCTION}

Diabetes is divided into type 1 diabetes from lack or deficiency of insulin hormone and type 2 diabetes caused by insulin resistance. Among these two types, type 2 diabetes is responsible for more than $95 \%$ of all diabetes patients (Kim et al., 2011). Diabetes can be classified according to blood sugar levels into normal blood sugar level, diabetic blood sugar level, and impaired fasting blood sugar as a pre-diabetes. Impaired fasting blood sugar corresponds to a high risk of type 2 diabetes, and it has been receiving great interest as a research target to prevent diabetes (Chun, 2011). Type 2 diabetic patients uses the highest medical expense among single diseases, and mortality rate of type 2 diabetes is also increasing (Lee et al., 2014). Rapid increase in type 2 diabetes is expected to reach 333 million globally 2025, bringing anxiety for the medical and political world (Van et al., 2005).

With expectation of further increase in the number of type 2 diabetes patients from the aging population, one of the reasons for social and national concerns is that it shows high incidence of complications (Choi and Jo, 2013). High blood sugar of diabetes increases prevalence of vascular

* Received: September 27, 2016 / Revised: October 6, 2016 / Accepted: October 13, 2016

${ }^{\dagger}$ Corresponding author: Yun-Jung Kang. Department of Clinical Laboratory Science, Kyungwoon University, Gumi 39160, Korea. Tel: +82-54-479-1308, Fax: +82-54-479-1308, e-mail: yjkang@ikw.ac.kr

(C) The Korean Society for Biomedical Laboratory Sciences. All rights reserved.

(c) This is an Open Access article distributed under the terms of the Creative Commons Attribution Non-Commercial License (http://creativecommons.org/licenses/by-nc/3.0/) which permits unrestricted non-commercial use, distribution, and reproduction in any medium, provided the original work is properly cited. 
injury, diabetic microvessel, and complication of large vessels to cause coronary artery disease, stroke, eye disease, diabetic foot disease, and diabetic nephrosis (Winocour, 2002). Furthermore, it is a risk factor of cardiovascular diseases (Klein et al., 1984). Type 2 diabetes is a disease that has both genetic factors and environmental factors (Bi, 2012). All factors need to be studied for prevention of the disease. However, whereas there are many studies that focus on genetic factors (Jung and Jin, 2016), individual life habits and individual behavior, there is a lack of studies that account for social context, namely social environment.

Social environment includes social support. Social support can be described in a broad sense as a resource provided by others (Cohen and Wills, 1985). There are many types of social support, but it is useful to classify it into two broad categories such as emotional support and instrumental support. Emotional support includes affection, interest, and respect, and instrumental support includes direct actions of help such as nursing, physical help, helping house chores, and material support (Berkman and Syme, 1979). The three pathways through which social support affects physical health can be summarized as health behavior pathway, psychological pathway, and physiological pathway. First, health behavior pathway affects health promotion or hazardous behaviors such as smoking, drinking, physical activities, and dietary habits (Lewis and Rook, 1999). Second, psychological pathway affects cognitive and emotional conditions like self-esteem, social competency, self-efficacy, depression, and emotion (Cohen, 1988). Lastly, physiological pathway shows buffering action on bad influences such as increase of blood pressure from stress response, excessive stimulation with increase of catecholamine, and suppression of immune reaction. Oxytocin is a neuroendocrine hormone that can have direct impact on the health outcome by reducing blood pressure and showing anti-stress activity (Uchino et al., 1996).

Accordingly, the aim of this study is to classify diabetes into impaired fasting blood sugar as a pre-diabetes and diabetes, to examine the effect of social support on type 2 diabetes and its scope, to reveal that diseases of individuals are caused by social relations and interactions, and to explore the cause of diseases from the perspective of social relations.

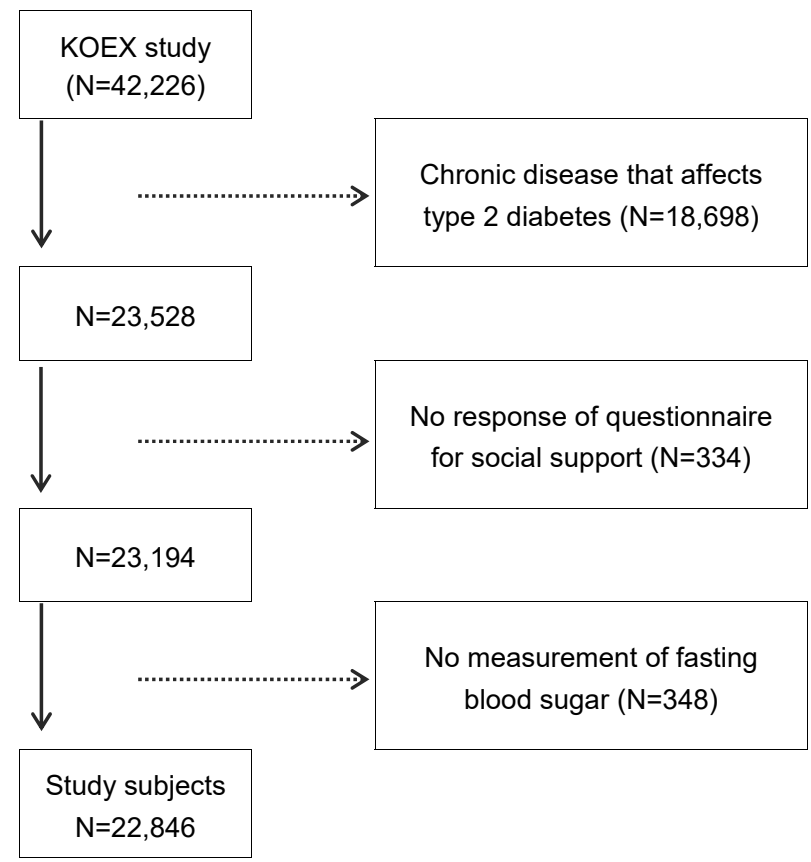

Fig. 1. Selection process of the study subjects.

\section{MATERIALS AND METHODS}

\section{Data and study subjects}

Study participant agreed and registered to participate in the "Korean Health Examine Cohort (KOEX)" study which simultaneously collects questionnaires and biological samples at 8 university hospitals around the nation. This database is intended to examine and manage risk factors related to occurrence of chronic diseases such as diabetes, hypertension, osteoporosis, respiratory diseases, and metabolic syndrome. Among 42,226 adults aged 30 years or above who registered for the 2nd 5th and 7th KOEX study in 2004 2010 (1st 7 th), 16,698 samples with history of chronic diseases which can affect type 2 diabetes (stroke, angina / myocardial infarction, hypertension, hyperlipidemia, thyroid disease, fatty liver, chronic hepatitis / cirrhosis, asthma, arthritis, cataract, osteoporosis, and cancer) were excluded. Subjects of this study include 22,846 persons with sufficient data related to social support and diabetes, primary variables of this study (Fig. 1). 


\section{Data collection}

All subjects were requested to fill out a self-administered questionnaire on socio-demographic characteristics like sex, age, education, income and marital status, health-related life habits such as smoking, drinking, physical activities, subjective health status and psychosocial stress, history of diseases, medication, and family history of diseases.

\section{Body measurements}

Body measurements (height, weight, and waist) were done while wearing thin clothes, Body Mass Index was calculated by dividing square of height into weight. Subjects were divided according to BMI into underweight for BMI below $18.5\left(\mathrm{~m} / \mathrm{kg}^{2}\right)$, normal for $18.5 \sim 23\left(\mathrm{~m} / \mathrm{kg}^{2}\right)$, overweight for $23 \sim 25\left(\mathrm{~m} / \mathrm{kg}^{2}\right)$, and obese for $25\left(\mathrm{~m} / \mathrm{kg}^{2}\right)$ or above (Wen et al., 2009).

\section{Dependent variable: The definition of the diabetes}

Fasting blood sugar (FBS) and FBS analysis involved serum separation from blood collected using SST $5 \mathrm{~mL}$ tube (Sekisui Chemical Co, Osaka, Japan) within 30 minutes and measurement by UV test (Hexokinase Assay) using modular analytics P800 (Hitachi /Naka/Japan). In the first step of the test, hexokinase uses ATP to phosphorylate glucose and form glucose-6-phosphate. In the second step, G-6-PDH oxidizes G-6-P to gluconate-6-P in NADP. Yield of NADPH formed during the reaction is directly proportional to glucose concentration. Absorbance is measured at $340 \mathrm{~nm}$ or $700 \mathrm{~nm}$, and the result is automatically calculated in comparison to calibration curve. Diabetes was defined based on the standard set forth by American Diabetes Association (ADA, 1997). Fasting blood sugar below $100 \mathrm{mg} / \mathrm{dL}$ as defined as normal, prediabetes (impaired fasting blood sugar) as 100 125 mg /dL, and diagnosis of diabetes as blood sugar level of 126 $\mathrm{mg} / \mathrm{dL}$ or above, diagnosis by a doctor, or medication of insulin or oral hypoglycemic agent.

\section{Predictor: Social support}

Scale of He (He, 2000) was used as the scale for social support. The questionnaire consisted of six questions on positive support and six questions on negative support.
Coefficient of Kuder-Richardson Formula 20 (KR-20) was 0.80 for 6 questions on positive support and 0.72 for 6 questions on negative support, and the functional score scale of social support showed high reliability. 6 questions on positive support include 3 questions on emotional support such as 'There is a person to whom I can share my feelings', 'There is a person who cares about me', and 'There is a person who offers advices for important and difficult situations' and 3 questions on instrumental support such as 'There is a person who nurses me or helps house chores when I am sick', 'There is a person who lends me a hand when I am in need', and 'There is a person who is willing to spend time and help house chores whenever I ask'. Responses to these questions were no (1) and yes (2), and scores were totaled. Therefore, range of scores for positive support is $6 \sim 12$ points. Higher score refers to high social support, and subjects were divided into high and low groups based on the average value. Six questions on negative support include 'Many people interfere with or oppose what I do', 'There is a person who criticizes that all of my problems are created by myself', 'There is a person who seems to ignore me', 'There is a person who makes me uncomfortable by providing unnecessary help', 'There is a person around me who is indifferent about what I do', and 'There is a person who rejects when I ask for help'. Responses to the questions were no (1) and yes (2), and scores were totaled. Range of scores for negative support is $6 \sim 12$ points. Higher score refers to high negative support, and subjects were divided into high and low groups based on the average value.

\section{Social support groups}

Social support groups were divided into 4 groups. Group 1 (G1) had high positive and low negative supports. Group 2 (G2) had low positive and low negative supports. Group 3 (G3) had high positive and high negative supports, and Group 4 (G4) had low positive and high negative supports. Among them, Group 1 (G1) was the reference group with the highest social support.

\section{Statistical methods}

The final data were analyzed using SPSS 18.0 (SPSS Inc., Chicago, USA) Windows ver. Frequency analysis and 
Table 1. General characteristics and variables

\begin{tabular}{|c|c|c|c|}
\hline \multicolumn{2}{|c|}{ Characteristics \& variables } & \multirow{2}{*}{$\begin{array}{c}\begin{array}{c}\text { All } \\
(\mathrm{n}=22,846)\end{array} \\
7,657\end{array}$} & \multirow{2}{*}{$\begin{array}{c}\% \\
33.5\end{array}$} \\
\hline \multirow{2}{*}{ Sex } & Male & & \\
\hline & Female & 15,189 & 66.5 \\
\hline \multirow{5}{*}{ Age (years) } & $30 \sim 39$ & 118 & 0.5 \\
\hline & $40 \sim 49$ & 11,054 & 48.4 \\
\hline & $50 \sim 59$ & 8,425 & 36.9 \\
\hline & $60 \sim 69$ & 3,003 & 13.1 \\
\hline & $>70$ & 246 & 1.1 \\
\hline \multirow{5}{*}{$\begin{array}{l}\text { Education } \\
\text { level }\end{array}$} & Elementary & 3,075 & 13.7 \\
\hline & Middle & 3,449 & 15.3 \\
\hline & High & 8,703 & 38.7 \\
\hline & College & 7,274 & 32.3 \\
\hline & Unknown & 345 & \\
\hline \multirow{5}{*}{$\begin{array}{l}\text { Household } \\
\text { income } \\
\text { (10 thousand } \\
\text { KW/month) }\end{array}$} & $<200$ & 5,095 & 26.4 \\
\hline & $200 \sim 400$ & 8,355 & 43.3 \\
\hline & $400 \sim 600$ & 3,948 & 20.5 \\
\hline & $\geq 600$ & 1,899 & 9.8 \\
\hline & Unknown & 3,549 & \\
\hline \multirow{3}{*}{ Marital status } & Single & 2,038 & 9.0 \\
\hline & married & 20,711 & 91.0 \\
\hline & Unknown & 97 & \\
\hline \multirow{4}{*}{$\begin{array}{l}\text { Self-rated } \\
\text { health }\end{array}$} & Good & 9,870 & 43.5 \\
\hline & Medium & 9,929 & 43.7 \\
\hline & $\mathrm{Bad}$ & 2,899 & 12.8 \\
\hline & Unknown & 148 & \\
\hline \multirow{4}{*}{ Smoking } & Never & 16,841 & 74.0 \\
\hline & Former & 2,932 & 12.9 \\
\hline & Current & 2,972 & 13.1 \\
\hline & Unknown & 101 & \\
\hline \multirow{4}{*}{$\begin{array}{l}\text { Alcohol } \\
\text { intake }\end{array}$} & Never & 11,900 & 52.2 \\
\hline & Former & 678 & 3.0 \\
\hline & Current & 10,199 & 44.8 \\
\hline & Unknown & 69 & \\
\hline \multirow{5}{*}{$\begin{array}{l}\text { Body mass } \\
\text { index }\end{array}$} & Under weight & 455 & 2.0 \\
\hline & Normal & 9,242 & 41.4 \\
\hline & Over weight & 6,215 & 27.9 \\
\hline & Obesity & 6,401 & 28.7 \\
\hline & Unknown & 533 & \\
\hline \multirow{3}{*}{$\begin{array}{l}\text { Psychosocial } \\
\text { well-being } \\
\text { index }^{\dagger}\end{array}$} & Low & 19,662 & 89.2 \\
\hline & High & 2,376 & 10.8 \\
\hline & Unknown & 808 & \\
\hline
\end{tabular}

Table 1. General characteristics and variables (Continued)

\begin{tabular}{|c|c|c|c|}
\hline \multicolumn{2}{|c|}{ Characteristics \& Variables } & $\begin{array}{c}\text { All } \\
(n=22,846)\end{array}$ & $\%$ \\
\hline \multirow{4}{*}{$\begin{array}{l}\text { Leisure time } \\
\text { physical } \\
\text { activity } \\
(\mathrm{kcal} / \mathrm{wk})^{\ddagger}\end{array}$} & Mean \pm SD & \multicolumn{2}{|c|}{$187.36 \pm 238.84$} \\
\hline & Low & 12,927 & 65.1 \\
\hline & High & 6,923 & 34.9 \\
\hline & Unknown & 2,996 & \\
\hline \multirow{3}{*}{$\begin{array}{l}\text { Positive } \\
\text { support }\end{array}$} & Mean \pm SD & \multicolumn{2}{|c|}{$11.31 \pm 1.31$} \\
\hline & High & 15,881 & 15,881 \\
\hline & Low & 6,965 & 6,965 \\
\hline \multirow{3}{*}{$\begin{array}{l}\text { Negative } \\
\text { support }\end{array}$} & Mean \pm SD & \multicolumn{2}{|c|}{$6.64 \pm 1.16$} \\
\hline & Low & 15,434 & 15,434 \\
\hline & High & 7,412 & 7,412 \\
\hline $\begin{array}{l}\text { Fast blood } \\
\text { sugar }\end{array}$ & Mean \pm SD & \multicolumn{2}{|c|}{$92.54 \pm 18.49$} \\
\hline
\end{tabular}

descriptive statistics were used to determine general characteristics, and $P$ value was deduced by chi-square test to examine the relationship between general characteristics and fasting blood sugar. Multinomial logistic regression was performed to determine the relationship of social support with impaired fasting blood sugar and diabetes.

\section{Ethics statement}

The study was approved by the Institutional Review Board of Cheonan Dankook University. (IRB No. 2014-04-006). The data used for this study do not include any identifiable personal information. As such, informed consent was waived by the board.

\section{RESULTS}

\section{General characteristics and variables}

Total number of samples was 22,846 . There were slight differences in the number of effective samples for different characteristics. Looking into general characteristics, the ratio of females $(66.5 \%)$ was higher than males (33.5\%). Highest ratio of age was $40 \mathrm{~s}(49.3 \%)$. Highest ratio of educational background was shown by high school graduates (38.7\%). Highest ratio of income level was 2 4 million Won (43.3\%), and overwhelmingly many subjects were married $(91.0 \%)$. Highest ratio of subjective health status was normal (43.7\%), 
Table 2. Fasting blood sugar according to general characteristics

\begin{tabular}{|c|c|c|c|c|c|}
\hline \multirow{2}{*}{\multicolumn{2}{|c|}{$\begin{array}{c} \\
\text { Characteristics } \\
\text { All }(\mathrm{n}=22,846)\end{array}$}} & \multicolumn{3}{|c|}{ FBS, n (\%) } & \multirow[b]{2}{*}{$P$-value } \\
\hline & & $\begin{array}{c}\text { Normal }^{*} \\
17790\end{array}$ & $\frac{\mathrm{IFG}^{\dagger}}{3490}$ & $\begin{array}{l}\mathrm{DM}^{\ddagger} \\
1558\end{array}$ & \\
\hline \multirow{2}{*}{ Sex } & Male & $5209(68.0)$ & $1748(22.8)$ & $700(9.1)$ & \multirow{2}{*}{$<0.001$} \\
\hline & Female & $12581(82.8)$ & $1750(11.5)$ & $858(5.6)$ & \\
\hline \multirow{5}{*}{ Age (years) } & $30 \sim 39$ & $106(89.8)$ & $6(5.1)$ & $6(5.1)$ & \multirow{5}{*}{$<0.001$} \\
\hline & $40 \sim 49$ & 9088 (82.2) & $1334(12.1)$ & $632(5.7)$ & \\
\hline & $50 \sim 59$ & 6305 (74.8) & $1486(17.6)$ & $634(7.5)$ & \\
\hline & $60 \sim 69$ & $2115(70.4)$ & $621(20.7)$ & $267(8.9)$ & \\
\hline & $>70$ & $176(71.5)$ & $51(20.7)$ & $19(7.7)$ & \\
\hline \multirow{5}{*}{ Education level } & Elementary & $2271(73.9)$ & $535(17.4)$ & $269(8.7)$ & \multirow{5}{*}{$<0.001$} \\
\hline & Middle & $2610(75.7)$ & $575(16.7)$ & $264(7.7)$ & \\
\hline & High & $6878(79.0)$ & $1273(14.6)$ & $552(6.3)$ & \\
\hline & College & 5765 (79.3) & $1057(14.5)$ & $452(6.2)$ & \\
\hline & Unknown & $324(1.5)$ & & & \\
\hline \multirow{5}{*}{$\begin{array}{l}\text { Household income } \\
\text { (10 thousand } \\
\text { KW/month) }\end{array}$} & $<200$ & $3836(75.3)$ & $870(17.1)$ & $389(7.6)$ & \multirow{5}{*}{$<0.001$} \\
\hline & $200 \sim 400$ & $6534(78.2)$ & $1262(15.1)$ & $559(6.7)$ & \\
\hline & $400 \sim 600$ & $3179(80.5)$ & $539(13.7)$ & $230(5.8)$ & \\
\hline & $\geq 600$ & $1534(80.8)$ & $256(13.5)$ & $109(5.7)$ & \\
\hline & Unknown & $3278(15.4)$ & & & \\
\hline \multirow{3}{*}{ Marital status } & Single & $1605(78.8)$ & $315(15.5)$ & $118(5.8)$ & \multirow{3}{*}{0.148} \\
\hline & married & $16103(77.8)$ & $3172(15.3)$ & $1436(6.9)$ & \\
\hline & Unknown & $93(0.4)$ & & & \\
\hline \multirow{4}{*}{ Self-rated health } & Good & 7694 (78.0) & $1530(15.5)$ & $646(6.5)$ & \multirow{4}{*}{0.005} \\
\hline & Medium & $7790(78.5)$ & $1481(14.9)$ & $658(6.6)$ & \\
\hline & $\mathrm{Bad}$ & $2200(75.9)$ & 457 (15.8) & $242(8.3)$ & \\
\hline & Unknown & $136(0.6)$ & & & \\
\hline \multirow{4}{*}{ Smoking } & Never & $13700(81.3)$ & $2131(12.7)$ & $1010(6.0)$ & \multirow{4}{*}{$<0.001$} \\
\hline & Former & $1946(66.4)$ & $725(24.7)$ & $261(8.9)$ & \\
\hline & Current & $2052(69.0)$ & $638(21.5)$ & $282(9.5)$ & \\
\hline & Unknown & $96(0.5)$ & & & \\
\hline \multirow{4}{*}{ Alcohol intake } & Never & $9609(80.7)$ & $1520(12.8)$ & $771(6.5)$ & \multirow{4}{*}{$<0.001$} \\
\hline & Former & $505(74.5)$ & $129(19.0)$ & $44(6.5)$ & \\
\hline & Current & 7617 (74.7) & $1843(18.1)$ & $739(7.2)$ & \\
\hline & Unknown & $65(0.3)$ & & & \\
\hline \multirow{5}{*}{ Body mass index ${ }^{\S}$} & Under weight & $392(86.2)$ & $39(8.6)$ & $24(5.3)$ & \multirow{5}{*}{$<0.001$} \\
\hline & Normal & $7688(83.2)$ & $1034(11.2)$ & $520(5.6)$ & \\
\hline & Over weight & $4801(77.2)$ & $1014(16.3)$ & $400(6.4)$ & \\
\hline & Obesity & $4508(70.4)$ & $1324(20.7)$ & $569(8.9)$ & \\
\hline & Unknown & $488(2.3)$ & & & \\
\hline \multirow{3}{*}{$\begin{array}{l}\text { Psychosocial } \\
\text { well-being index }\end{array}$} & Low & $15319(77.9)$ & $2997(15.2)$ & $1346(6.8)$ & \\
\hline & High & $1857(78.2)$ & $369(15.5)$ & $150(6.3)$ & 0.601 \\
\hline & Unknown & $746(3.5)$ & & & \\
\hline
\end{tabular}


Table 2. Fasting blood sugar according to general characteristics (Continued)

\begin{tabular}{|c|c|c|c|c|c|}
\hline \multirow{3}{*}{\multicolumn{2}{|c|}{$\begin{array}{l}\text { Characteristics } \\
\text { All }(n=22,846)\end{array}$}} & \multicolumn{3}{|c|}{ FBS, n (\%) } & \multirow{3}{*}{$P$-value } \\
\hline & & Normal $^{*}$ & $\mathrm{IFG}^{\dagger}$ & $\mathrm{DM}^{*}$ & \\
\hline & & 17790 & 3490 & 1558 & \\
\hline \multirow{3}{*}{$\begin{array}{l}\text { Leisure time } \\
\text { physical activity } \\
\text { (kcal/wk) }\end{array}$} & Low & $10083(78.0)$ & $1931(14.9)$ & $913(7.1)$ & \multirow{3}{*}{0.017} \\
\hline & High & $5316(76.8)$ & $1139(16.5)$ & $468(6.8)$ & \\
\hline & Unknown & $2819(13.2)$ & & & \\
\hline
\end{tabular}

${ }^{*}$ Normal, FBS $<100 \mathrm{mg} / \mathrm{dL}$

†IFG: Impaired Fasting Glucose, FBS 100 125 mg/dL

DM: Diabetes Mellitus, FBS $\geq 126 \mathrm{mg} / \mathrm{dL}$

${ }^{\S}$ Body mass index; Underweight (BMI $\left.<18.5\right)$, Normal $(18.5 \leq$ BMI $<23)$, Overweight $(23 \leq$ BMI $<25)$, Obesity $(\mathrm{BMI} \geq 25)$

"Psychosocial well-being index; Low risk group (PWI <27), High risk group (PWI $\geq 27)$

"Leisure time physical activity; Low activity group (tLTPA $<$ average), High activity group (tLTPA $\geq$ average)

and the ratios of non-smoking $(74.0 \%)$ and non-drinking $(52.2 \%)$ subjects were highest. Highest ratio of BMI was normal $(41.4 \%)$, and the ratio of low psychosocial stress risk was high (89.2\%). Physical leisure activities were low (65.1\%) compared to average. More subjects (69.5\%) showed higher positive support than overall average, and more subjects $(67.6 \%)$ showed lower negative support than overall average. Average fasting blood sugar was 92.54 ( \pm 18.49$)$ and belonged to normal category (Table 1).

\section{General characteristics according to categories of fasting blood sugar}

Looking at the relationship between general characteristics and fasting blood sugar, significant differences were found in terms of sex, age, education, household income, subjective health status, smoking, drinking, BMI and physical leisure activities excluding marital status and psychosocial stress. The ratio of abnormal fasting blood sugar was higher in males compared to females, and increasing age was found to increase the risk of impaired fasting blood sugar or diabetes. In addition, low education and income resulted in significantly high ratio of abnormal fasting blood sugar. Clear difference in subjective health status was shown by diabetes-risk group in comparison to normal group and impaired fasting blood sugar group. This was the same for drinking and smoking experiences, and abnormal fasting blood sugar was further increased by increase of BMI. Low physical leisure activities showed higher risk of diabetes
(Table 2).

\section{The effect of social support on fasting blood sugar}

For the relationship between social support and impaired fasting blood sugar (FBS $\geq 100 \mathrm{mg} / \mathrm{dL}$ ), the group (G3) with high positive support and negative support showed prevalence rate of impaired fasting blood sugar 1.17 times (95\% CI $=1.06 \sim 1.29)$ higher than the group (G1) with high positive support and low negative support during univariate analysis. Different aspects were shown according to sex. For males, both the group $(\mathrm{G} 2)$ with low positive and negative supports and the group (G3) with high positive and negative supports had prevalence rate of impaired fasting blood sugar 1.18 1.20 times higher than the group (G4) with low positive support and high negative support. For females, only the group (G2) with low positive and negative supports showed prevalence rate 1.17 times $(95 \% \mathrm{CI}=1.02 \sim$ 1.34) higher than G1.

In multivariate analysis that corrected for sample characteristics possibly related to impaired fasting blood sugar and diabetes, prevalence of the group (G3) with high positive and negative supports was 1.15 times $(95 \% \mathrm{CI}=1.02 \sim 1.29)$ higher than the group (G1) with high positive support and low negative support. However, the results were insignificant for all groups. For females, prevalence rate of impaired fasting blood sugar of the group (G3) with high positive and negative supports was 1.19 times $(95 \% \mathrm{CI}=1.01 \sim$ 1.41) higher than G1. The relationship between social support 
Table 3. The effect of social support on fasting blood sugar

\begin{tabular}{|c|c|c|c|c|c|}
\hline & & & ALL & Male & Female \\
\hline \multirow{8}{*}{$\mathrm{IFG}^{*}$} & \multirow{4}{*}{$\begin{array}{c}\text { Crude OR } \\
(95 \% \text { CI })\end{array}$} & G1 & 1 & 1 & 1 \\
\hline & & $\mathrm{G} 2$ & $1.08(0.97 \sim 1.19)$ & $1.20(1.02 \sim 1.41)$ & $1.17(1.02 \sim 1.34)$ \\
\hline & & G3 & $1.17(1.06 \sim 1.29)$ & $1.18(1.03 \sim 1.36)$ & $1.13(0.99 \sim 1.30)$ \\
\hline & & G4 & $1.08(0.97 \sim 1.20)$ & $1.20(1.01 \sim 1.43)$ & $1.15(1.00 \sim 1.33)$ \\
\hline & \multirow{4}{*}{$\begin{array}{l}\text { Multivariate OR } \\
\qquad(95 \% \mathrm{CI})^{\ddagger}\end{array}$} & G1 & 1 & 1 & 1 \\
\hline & & G2 & $1.09(0.96 \sim 1.24)$ & $1.16(0.96 \sim 1.41)$ & $1.10(0.93 \sim 1.31)$ \\
\hline & & G3 & $1.15(1.02 \sim 1.29)$ & $1.14(0.97 \sim 1.33)$ & $1.19(1.01 \sim 1.41)$ \\
\hline & & G4 & $1.07(0.94 \sim 1.22)$ & $1.11(0.91 \sim 1.35)$ & $1.11(0.93 \sim 1.33)$ \\
\hline \multirow{8}{*}{$\mathrm{DM}^{\dagger}$} & \multirow{4}{*}{$\begin{array}{l}\text { Vrude OR } \\
(95 \% \mathrm{CI})\end{array}$} & G1 & 1 & 1 & 1 \\
\hline & & G2 & $0.94(0.81 \sim 1.09)$ & $1.11(0.88 \sim 1.42)$ & $0.94(0.77 \sim 1.14)$ \\
\hline & & G3 & $1.03(0.89 \sim 1.18)$ & $1.03(0.84 \sim 1.26)$ & $1.01(0.83 \sim 1.23)$ \\
\hline & & G4 & $0.95(0.81 \sim 1.11)$ & $1.00(0.77 \sim 1.29)$ & $1.01(0.82 \sim 1.23)$ \\
\hline & \multirow{4}{*}{$\begin{array}{l}\text { Multivariate OR } \\
\qquad(95 \% \mathrm{CI})^{\dagger}\end{array}$} & G1 & 1 & 1 & 1 \\
\hline & & G2 & $1.03(0.86 \sim 1.23)$ & $1.10(0.83 \sim 1.46)$ & $1.03(0.82 \sim 1.30)$ \\
\hline & & G3 & $0.99(0.84 \sim 1.17)$ & $1.00(0.79 \sim 1.26)$ & $1.00(0.79 \sim 1.27)$ \\
\hline & & G4 & $0.97(0.81 \sim 1.17)$ & $0.97(0.72 \sim 1.30)$ & $1.03(0.80 \sim 1.31)$ \\
\hline
\end{tabular}

G1: high positive and low negative support

G2: low positive and low negative support

G3: high positive and high negative support

G4: low positive and high negative support

*IFG: Impaired Fasting Glucose, FBS 100 125 mg/dL

'DM: Diabetes Mellitus, FBS $\geq 126 \mathrm{mg} / \mathrm{dL}$

Adjusted by Age, Education Level, Household Income, Self-rated Health, Smoking, Drinking, Body Mass Index, Leisure Time Physical Activity

and diabetes (FBS $\geq 126 \mathrm{mg} / \mathrm{dL}$ ) was statistically insignificant in both univariate analysis and multivariate analysis (Table 3).

\section{DISCUSSION}

Prevalence rate of impaired fasting blood sugar was found to increase in the female group (G3) with high positive and negative supports, and the relationship between social support and diabetes was statistically insignificant. Positive support affects health behaviors such as drinking, smoking, physical activities, sexual behavior, and substance abuse, and it affects health through diverse psychological and physiological pathways like buffering action on stress (Berkman et al., 2000). In contrast, negative support not only causes scarcity of resources to cope with stress situations but also has harmful effects on health as individual source of stress (Vinokur and van, 1993). Therefore, positive support and negative support seem to have different effects on health. As a result of analyzing positive support and negative support, this study confirmed that prevalence rate of impaired fasting blood sugar is highest in the female group with high positive and negative supports. This result probably implies that high positive support shows opposite effects when negative support is also high. It is similar to the study result of Boehm (Boehm et al., 1997) that higher social support than desired can be experienced as nitpicking and harassment, and can have negative effect on compliance with dietary therapy. Another study result (Camille et al., 1985) showed that greater social support can further increase depressive symptom. This means that positive support can be recognized as nitpicking or harassment and bring side effects when negative support is high.

Negative function in a social relation has harmful effect on 
mental health independent from positive function (Berkman et al., 2000), and some studies conclude that negative support has greater influence on mental conditions than positive support (Baumeister et al., 2001). Also in this study, there was a difference in prevalence rate of impaired fasting blood sugar about social support among sexes. Considering the fact that social status and influence of females are lower than males (Carli, 2001) and negative social relation results in greater psychological pain, relative vulnerability of females might have shown more sensitive effect of negative function on health (Schuster et al., 1990). This partially agrees with the result of a study conducted by Norberg (Norberg et al., 2007) that low emotional support increases development of type 2 diabetes in females but not in males. A study on the effect of social relations on glucose control reported that social integration reduces risk of type 2 diabetes in females and increases its risk in males (Agneta et al., 2015). Thus, social relations can affect blood sugar control differently between males and females.

While affecting psychological factors like self-esteem, sense of belonging, optimism, and stress management, positive social support generally has beneficial effects on health (Geckova et al., 2003) and can also affect healthier lifestyle in the end. In addition, low social support was demonstrated to increase psychosocial tension and stress, contributing to persistent difference in response of hypothalamic-pituitaryadrenal (HPA) axis (Seeman and Crimmins, 2001). Poor, inefficient and exaggerated response of HPA axis causes reduced sensitivity to insulin, steroid-induced diabetes, hypertension, hyperlipidemia, artery disease, and immunosuppression (Francis et al., 1996). Increase of catecholamine and cortisol increases risk factors of type 2 diabetes such as generation of hepatic glucose, reduced insulin sensitivity, fat accumulation, and increased hypertension. This is supported by a study (Strom and Egede, 2012) on diabetes patients related to psychosocial results with improvement of fasting blood sugar, blood pressure, and lipid by high level of social support. The results of this study verified the effect of social support on impaired fasting blood sugar, a previous step of type 2 diabetes. The reason why social support only affected impaired fasting blood sugar while it also affected diabetes in previous studies (Norberg et al.,
2007; Agneta et al., 2015) is because subjects of this study are persons who received health examination.

A study (Hong and Park, 2014) that surveyed prevalence rate of diabetes using primitive data from Korea Health and Nutrition Examination Survey of 2012 showed diabetes prevalence rate of $10.5 \%$, whereas prevalence rate of diabetes was $6.8 \%$ in this study. People who receive health examination are known to have greater interest in health and place much effort into disease prevention compared to others. Patients with impaired fasting blood sugar tried to prevent development of diabetes by recognizing and managing prediabetes which involves high risk of diabetes. In fact, high ratio of subjects of this study with impaired fasting blood sugar responded that they smoked and drank in the past but not anymore. Although statistically insignificant, they showed high physical activities.

The current study does have its limitations. First, this is a cross sectional study and therefore cannot discuss the causal relationship between social supports and impaired fasting blood sugar. In case of diabetes patients, there may be a reverse causality in which social support is increased by interest of surrounding people. Second, since subjects of this study were limited to a specific population group of people who received health examination, the results of this study cannot be generalized. Third, diabetes was only diagnosed based on fasting blood sugar without glucose tolerance test. Fourth, whereas the effects of social support vary depending on who provides the support, sources of support were not taken into account in this study. Therefore, a future study must be conducted to make improvement on these limitations. Despite such limitations, this study examined the relationship between social support and impaired fasting blood sugar in regards to sex using data collected from questionnaires and biological samples at 8 university hospitals around the nation. The meaning of this study is in comprehensive exploration of the cause of disease from the context of social relations, breaking away from biological approach to personal health problems.

In conclusion, as this study verified the effect of social support on increase of fasting blood sugar in females after correcting for socio-economic status, health behavior, and biological and medical variables, it is necessary to account 
for social relations like social support in addition to personal risk factors for prevention of type 2 diabetes. Also, the difference in the relationship between social support and increase of blood sugar among sexes suggests that sexual difference must be considered in understanding and utilizing the influence of social support. Unlike many studies that only focused on the effect of positive support on health management, the result of this study showing adverse effect of high positive support with high negative support implies that the effect of negative support must be considered as well.

\section{Conflict of interest}

The authors have no financial conflicts of interest.

\section{REFERENCES}

ADA International expert committee: report of the expert committee on the diagnosis and classification of diabetes mellitus. Diabetes Care. 1997. 20: 1183-1197.

Hilding A, Shen C, Ostenson CG. Social network and development of prediabetes and type 2 diabetes in middle-aged Swedish women and men. Diabetes Res Clin Pract. 2015. 107: 166-177.

Baumeister RF, Bratslavsky E, Finkenauer C, Vohs KD. Bad is stronger than good. Rev Gen Psychol. 2001. 5: 323-370.

Berkman LF, Syme SL. Social networks, host resistance, and mortality: a nine-year follow-up study of Alameda county residents. Am J Epidemiol. 1979. 109: 186-204.

Berkman LF, Glass T, Brissette I, Seeman TE. From social integration to health: Durkheim in the new millennium. Social Science \& Medicine. 2000. 51: 843-857.

Bi Y, Wang T, Xu M, Xu Y, Li M, Lu J, Zhu X, Ning G, et al. Advanced research on risk factors of type 2 diabetes. Diabetes Metab Res Rev. 2012. 28: 32-39.

Boehm S, Schlenk E, Funnell MM, Powers H, Ronis DL. Predictors of adherence to nutrition recommendations in people with non-insulin dependent diabetes mellitus. Diabetes Educ. 1997. 23: 157-165.

Camille B. Wortman, Darrin R. Lehman. Reactions of victims to life crisis: support attempts that fail. Social Support: Theory, Research and Applications. 1985. 24: 463-489.

Chun KH. Evidence-based management and treatment of high-risk individuals with pre-diabetes. J Korean Med Assoc. 2011. 54: 1020-1027.
Choi MJ, Jo HJ. Effects of green tea powder on bone markers and bone mineral density in STZ-Induced diabetic rats. J East Asian Soc Dietary Life. 2013. 23: 713-722.

Cohen S, Wills TA. Stress, social support, and the buffering hypothesis. Psychol. 1985. 98: 310-357.

Cohen S. Psychosocial models of the role of social support in the etiology of physical disease. Health Psychol. 1988. 7: 269-297.

Francis D, Diorio J, LaPlante P, Weaver S, Seck1 JR, Meaney MJ. The role of early environmental events in regulating neuroendocrine development moms, pups, stress and glucorticoid receptors. Ann NY Acad Sci. 1996. 794: 136-152.

Geckova A, van Dijk JP, Stewart R, Groothoff JW, Post D. Influence of social support on health and socio-economic groups of adolescents. Eur J Publ Health. 2003. 3: 44-50.

He SY. The social networks and life satisfaction of the low-income elderly living alone. Seoul National University Press. 2000.

Hong JY, Park JA. Effect of health status and health behavior on the diabetes mellitus prevalence of Korean adults. J. Contents Association. 2014. 14: 198-220.

Jung DJ, Jin HS. Association analysis between genes' variants for regulating mitochondrial dynamics and fasting blood glucose level. Biomed Sci Lett. 2016. 22: 107-114.

Kim MK, Choi AR, Han GS, Jeong SG, Jeong MO, Kim DH, Ham, JS. Dairy products intake and managing diabetes. Korean J Dairy Sci Technol. 2011. 29: 17-22.

Klein R, Klein BE, Moss SE, Davis MD, DeMets DL. The Wisconsin epidemiologic study of diabetic retinopathy. III Prevalence and risk of diabetic retinopathy when age at diagnosis is 30 or more years. Arch Opthalmol. 1984. 102: 527 -532 .

Lee HS, Kang HJ, Jeon IH, Youm JH, Jang SI. Anti-diabetic effects of sprouts in high-fat diet and streptozotocin-induced type II diabetes mellitus mice. J Korean Soc Food Sci Nut. 2014. 43 1558-1564.

Lewis MA, Rook KS. Social control in personal relationships: Impact on health behaviors and psychological distress. Health Psychol. 1999. 18: 63-71.

Norberg M, Stenlund H, Lindahl B, Andersson C, Eriksson JW, Weinehall L. Work stress and low emotional support is associated with increased risk if future type 2 diabetes in women. Diabetes Res Clin Pract. 2007. 76: 368-377.

Schuster TL, Kessler RC. Aseltine RH. Jr. Supportive interactions, negative interactions, and depressed mood. Am J Community Psychol. 1990. 18: 423-438.

Seeman TE, Crimmins E. Social environment effects on health 
and aging. Ann NY Acad Sci. 2001. 954: 88-117.

Strom JL, Egede LE. The impact of social support on outcomes in adult patients with type 2 diabetes: a systematic review. Curr Diabetes Rep. 2012. 12: 769-781.

Uchino, BN, Cacioppo JT, Kiecolt-Glaser JK. The relationship between social support and physiological processes: a review with emphasis on underlying mechanisms and implications for health. Psychol. 1996. 119: 488-531.

van Dam HA, van der Horst FG, Knoops L, Ryckman RM, Crebolder HF, van den Bome BH. Social support in diabetes: a systematic review of controlled intervention studies. Patient
Education and Counseling. 2005. 59: 1-2.

Vinokur AD, van Ryn M. Social support and undermining in close relationships: their independent effects on the mental health of unemployed persons. J Pers Soc Psychol. 1993. 65: 350-359.

Winocour PH. Effective diabetes care: a need for realistic targets. Br Med J. 2002. 324: 1577-1580.

Wen CP, David Cheng TY, Tsai SP, Chan HT, Hsu HL, Hsu CC, Eriksen MP, et al. Are Asians at greater mortality risks for being overweight than Caucasians? Redefining obesity for Asians. Public Health Nutr. 2009. 12: 497-506. 